\title{
The role of Fas ligand protein in the oxidative stress induced by azoxymethane on crypt colon of rats $^{1}$
}

\author{
O papel da proteína ligante Fas no estresse oxidativo induzido pelo azoximetano em criptas do \\ colo de ratos
}

\author{
Luiz Antonio Maksoud Bussuan ${ }^{\mathrm{I}}$, Djalma José Fagundes ${ }^{\mathrm{II}}$, Guido Marks ${ }^{\mathrm{III}}$, Priscila Maksoud Bussuan ${ }^{\mathrm{IV}}$, Roberto Teruya ${ }^{\mathrm{V}}$ \\ ${ }^{\mathrm{I}} \mathrm{MD}$, Fellow Master Degree, Postgraduate Program in Surgery and Experimentation, Division of Operative Technique and Experimental Surgery, \\ Department of Surgery, UNIFESP-SP, Brazil.

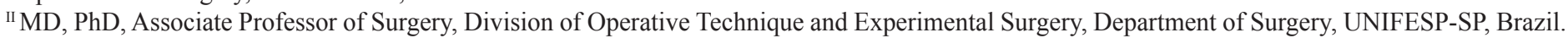 \\ ${ }^{\mathrm{III}} \mathrm{MD}, \mathrm{PhD}$, Assistant Professor, Department of Surgery, UFMS, Campo Grande-MS, Brazil. \\ ${ }^{\text {Iv }}$ MD, Dermatologist, Moreira Salles Institute (IMS), Rio de Janeiro-RJ, Brazil. \\ ${ }^{v}$ MD, Fellow PhD Degree, Postgraduate Program in Surgery and Experimentation, Department of Surgery, UNIFESP-SP, Brazil.
}

\begin{abstract}
Purpose: To study the protein Fas ligand (FasL) on the expression of apoptosis, using a model of oxidative stress induced by azoxymethane (AOM), in the crypt of colon in rats. Methods: Wistar rats $(n=14)$ were assigned into two groups: control ( $\mathrm{n}=7)$ and AOM ( $\mathrm{n}=7)$. A single subcutaneous administration of AOM $(5 \mathrm{mg} / \mathrm{kg})$ or saline solution was performed at the beginning of third week and after three hours samples of proximal colon were collected. The expression of FasL was quantified (Software ImageLab) in percentage of areas in the top, base and all crypt. Results were expressed as mean \pm sd (Shapiro-Wilks test and t Student test) $(\mathrm{p} \leq 0.05)$. Results: In the animals of CG there was no significant difference between the FasL expression of the top (10.75 \pm 3.33$)$ and basal (11.14 \pm 3.53$)$ colon crypt $(\mathrm{p}=0.34293740)$. In the animals of AOM there was no significant difference between the FasL expression of the top (8.86 \pm 4.19$)$ and basal $(8.99 \pm 4.08)$ colon crypt ( $\mathrm{p}=0.78486003)$. In the animals of CG $(10.95 \pm 3.43)$ and $\mathrm{AOM}$ $(8.92 \pm 4.13)$ there was a significant difference of the FasL expression $(\mathrm{p}=0.026466821)$. A significantly decrease on the FasL expression was observed in the animals of CG $(10.75 \pm 3.33)$ and AOM $(8.86 \pm 4.19)$ in the top crypt $\left(\mathrm{p}=0.00003755^{*}\right)$. A significant decrease was also observed in the animals of CG $(11.14 \pm 3.53)$ and AOM $(8.99 \pm 4.08)$ in the basal colon crypt ( $\mathrm{p}=0.00000381 * *)$. Conclusion: Azoxymethane induce the oxidative stress and the significantly decrease of FasL expression, although there is no significant difference between basal and top of colon crypt linked to consumption-activation of Fas ligand.
\end{abstract}

Key words: Fas Ligand Protein. Azoxymethane. Oxidative Stress. Apoptosis. Rats.

\section{RESUMO}

Objetivo: Avaliar o marcador de apoptose Fas ligante (FasL) em um modelo de estresse oxidativo induzido pelo azoximetano $(\mathrm{AOM})$ na cripta de cólon em ratos. Métodos: 14 ratos Wistar foram distribuídos em dois grupos: controle ( $\mathrm{n}=7)$ e AOM (n=7). A $\operatorname{AOM}(5 \mathrm{mg} / \mathrm{kg})$ ou solução salina foi aplicada via subcutânea e a coleta de amostras de colo proximal ocorreu 3 horas após. A FasL foi quantificada pelo percentual de áreas no topo, base e toda a cripta. Os resultados foram submetidos aos testes de Shapiro-Wilks e t de Student $(\mathrm{p} \leq 0,05)$. Resultados: No grupo GC, não houve diferença significativa entre a expressão da FasL no topo (10,75 $\pm 3,33)$ e base $(11,14 \pm 3,53)$ da cripta $(p=0,34293740)$. No grupo AOM não houve diferença significativa entre a expressão da FasL no topo $(8,86 \pm 4,19)$ e base $(8,99 \pm 4,08)$ e cripta $(p=0,78486003)$. No grupo GC $(10,95 \pm 3,43)$ e AOM $(8,92 \pm 4,13)$, houve uma diferença significativa da expressão da FasL ( $\mathrm{p}=0,026466821)$. Redução significativa na expressão da FasL ocorreu nos em GC $(10,75 \pm 3,33)$ e $\operatorname{AOM}(8,86 \pm 4,19)$ no topo da cripta $\left(\mathrm{p}=0,00003755^{*}\right)$. Foi observada diminuição significativa em $\mathrm{GC}(11,14 \pm 3,53)$ e $\operatorname{AOM}(8,99 \pm 4,08)$ na base da cripta $(\mathrm{p}=0,00000381 * *)$. Conclusão: Azoximetano induziu o estresse oxidativo identificado pela diminuição significativa da expressão da FasL, embora não haja diferença significativa entre a base e parte superior da cripta associada à ativação de consumo do FasL.

Descritores: Proteína Ligante Fas. Azoximetano. Estresse Oxidativo. Apoptose. Ratos

${ }^{1}$ Research performed at the Surgery and Experimentation Postgraduate Program, Federal University of Sao Paulo (UNIFESP) and Experimental Carcinogenesis Laboratory of the Central Animal Facilities, Federal University of Mato Grosso do Sul (UFMS), Campo Grande-MS, Brazil. 


\section{Introduction}

Programmed cell death, apoptosis, is known to participate in biological processes of development, maintenance of tissue homeostasis and elimination of cancer cells. Malfunctions of apoptosis have been implicated in many forms of human diseases. Apoptosis may be caused by various inducers such as chemical compounds or proteins. The biochemical pathways of apoptosis are complex and depend on both the cells and the inducers. It involves receptor-mediated protease activation, cytolytic plasma protein interactions, and ultimately distinct morphological alterations. These alterations can be observed microscopically and include DNA degradation and margination, condensation of chromatin, cell membrane alterations and the formation of apoptotic cascade ch $^{1,2}$.

The Fas protein and Fas ligand (FasL) are two proteins that interact to activate one of the best defined apoptotic pathways. Fas and FasL are both members of the TNF (Tumor Necrosis Factor) family. The Fas is part of the transmembrane receptor family and the FasL is part of the membrane-associated cytokine family. The binding of Fas ligand with its receptor induces apoptosis. The Fas ligand-receptor interactions play an important role in the regulation of the immune system and the progression of cancer. Over expression of the FAS ligand on the cell surface has been shown to cause shedding of the protein, and the soluble form of the FAS ligand can actively trigger apoptosis by binding to $\mathrm{FAS}^{3,4}$.

There are strong evidences that the stem-cell population is concentrated at the base of the colon crypt, within the stem-cell niche formed by the stem cells themselves and mesenchymal cells that surround the crypt base ${ }^{5-8}$. Apoptosis marker positive cells were found mainly on the luminal epithelium of the normal colon and were present in crypts of the colon, in addition to the luminal epithelium, in pathological situations such as ulcerative colitis and colorectal adenomas $^{5-9}$. The use of these apoptosis marker to monitor the beneficial effects of chemopreventative interventions would be to reduce the development of colorectal cancer within the context of clinical trials ${ }^{5-8}$.

Given the increasing evidence that apoptosis may play a role either in the induction or propagation of neoplastic transformation, we undertook to develop a model to examine FasL interaction in colonic mucosa layer. Thus, our aim was investigate the role of azoxymethane, a well known oxidative stress inducer compound, in modulating the biomarker FasL in the colon crypt of rats.

\section{Methods}

\section{Animals and facilities}

The experimental protocol was approved by the Ethics Committee of the Federal University of Sao Paulo (\#0183/06) and ratified by animal Ethics Committee of Federal University of Mato Grosso do Sul (\#064/04). The rats were kept according to the norms of the Guide for the Care and Use of Laboratory Animals (Institute for Laboratory Animal Research, 1996) and to the ethical principles of the Brazilian Committee on Animal Experimentation (COBEA). It was designed as an experimental, randomized, controlled trial with blind assessment of the outcome.
Fourteen male Wistar rats, weight 280-320g), were housed in temperature $\left(22^{\circ} \mathrm{C} \pm 3^{\circ} \mathrm{C}\right)$, light-controlled environmental conditions with a 12-hour light-dark cycle (130 to 325 lux), humidity of $58 \pm 13 \%$, and given free access to water and standard pellet chow. All procedures were done in the laboratories of Experimental Carcinogenesis of the Central Animal Facilities (UFMS) and follow the guide of Toxics Drugs Manipulation.

\section{Experimental design}

The animals were randomly assigned into one of the two groups: Control group $(\mathrm{CG} / \mathrm{n}=7)$ and Azoxymethane group (AOM /n=7). Tail tattoos, made with an indelible black ink pen, were used to identify groups (CG and AOM) and individual animals (1 to 7 ) within each group.

\section{Drugs administration}

During two weeks the animals were acclimated to laboratory environment and observed the bodyweight curve. At the beginning of third week the azoxymethane (AOM $\mathrm{C}_{2} \mathrm{H}_{6} \mathrm{~N}_{2} \mathrm{O}$. Sigma, cat. A9517, lot 014K0719) was administered subcutaneously $(5 \mathrm{mg} / \mathrm{kg}$ ) to the animals of AOM group and to the animals of control group were given $0.9 \%$ saline solution subcutaneously $(10 \mathrm{ml} / \mathrm{kg})$. The volumes of both drugs were equivalents.

\section{Colon samples collecting and euthanasia}

At the end of the third hours, under intraperitoneal thiopental $(40 \mathrm{mg} / \mathrm{kg})$ anesthesia, it was performed a midline laparotomy, identified the terminal ileum and ascendant colon and excised en bloc. The euthanasia occurred by overdose of thiopental $(150 \mathrm{mg} / \mathrm{kg})$ until cardio respiratory arrest.

\section{Histological processing}

The intestine samples were incised along the antimesenteric border and the mucosa was washed with Ringer solution until removed all the macroscopic intestinal residues. A $1-\mathrm{cm}$ long segment was resected from the ascendant colon. The segment of colon wall was sandwiched between the two plates of a hinged perforated double holder in order to be maintained straightened, and the set was immersed in $10 \%$ buffered formaldehyde solution for 24 hours. Each sample was embedded in paraffin (with sample identification being preserved) and sectioned with a microtome (2-micrometer-thick sagital sections of colon wall). The sections were fixed on silanized glass slides.

\section{Immunohistochemistry procedure}

The colon was prepared with biological marker Fas Ligant (FasL, termination epitope - N20, cat. Santa Cruz, SC834 product, lot E2804; 1:100 dilution) and followed by secondary antibody anti-rat (Dako LSAB ${ }^{\mathrm{TM}}$, K609 product, lot 15068); revealer of color DAB (diaminobenzidine, Dako ${ }^{\mathrm{TM}}$, K3468 product, lot 01317, in 1:10 dilution); FasL expression was obtained as brown color areas. 


\section{Image capture and processing}

Optical microscopy evaluation was performed with a microscope $\left(\right.$ Nikon $^{\mathrm{TM}}$, mod. Elipse E200) equipped with $10 \mathrm{X}$ binocular lenses and a 40X/0.65 objective. The microscope was coupled to a video camera (Samsung ${ }^{\mathrm{TM}}$, mod. SCC131) connected to a microcomputer (Duron ${ }^{\mathrm{TM}} 750-\mathrm{MHz}$ processor, 128-MB RAM,
20-GB hard disk, Microsoft Windows ${ }^{\mathrm{TM}} 98 \mathrm{SE}$ ) through a video board (Pinnacle Studio ${ }^{\mathrm{TM}}$ PCTV, USB). The captured image was saved in individual archives with previous codification. All archives were submitted for optimization of the photographic quality with use of Adobe Photoshop ${ }^{\mathrm{TM}}$ Software 7.0 / image / adjusted / canal RGB / curves / automatic (Figure 1).

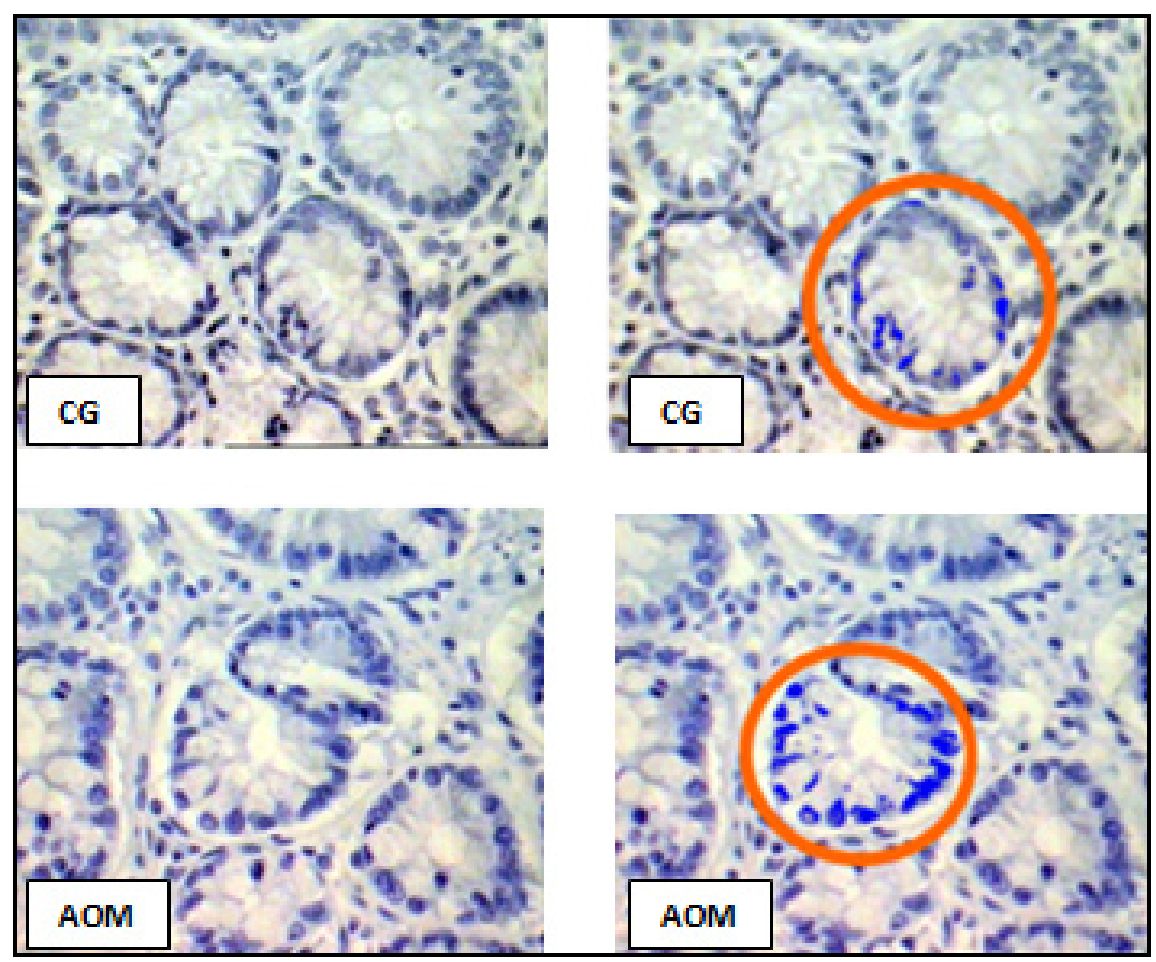

FIGURE 1 - Representative photomicrography of FasL expression (right side) and the blue label marks (lest side) using a RGB filter (circle). (Immunohistochemical - 40x)

\section{FasL quantification}

FasL was quantified by computer-assisted image processing with Image $\mathrm{Lab}^{\mathrm{TM}}$ software. Twenty single images from each sample were captured, always centered on the crypt. The optimized image crypts were randomly captured saved and codified scheme. The quantified brown coloration density corresponds to FasL expression in percentage area (using a RGB filter, blue background, 0-to-147 color interval) in the selected crypt. All histological analyses were performed by a single pathologist blinded to the origin of the groups (Figure 2).

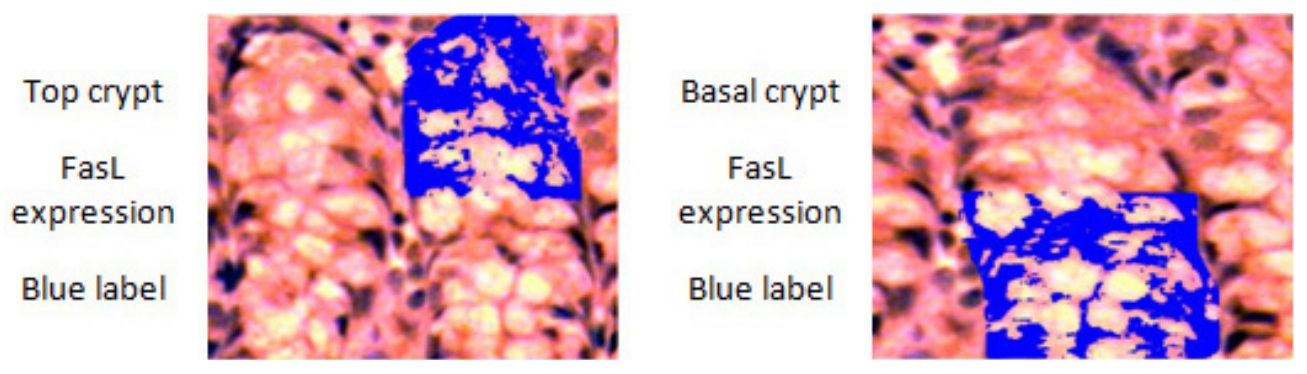

FIGURE 2 - FasL quantified by computer-assisted image processing with Image Lab ${ }^{\mathrm{TM}}$ software. The quantified brown coloration density corresponds to FasL expression in percentage area (using a RGB filter, blue background, 0-to-147 color interval) in the selected crypt. (Immunohistochemical - 400X) 


\section{Statistical analysis}

Parametric results were expressed as mean \pm standard deviation and Shapiro-Wilks test was performed to check the normality of the data before running the $t$ student test (Statistical program Epi-Info ${ }^{\mathrm{TM}}$ and BioEstat $\left.{ }^{\mathrm{TM}}\right)$. A 95\% confidence interval and a $5 \%$ significance level $(\mathrm{p} \leq 0.05)$ were adopted.

\section{Results}

The means and standard deviation of the percentage area $\left(\mu \mathrm{m}^{2}\right)$ of biomarker FasL in the colon crypt (entire, top and basal) in $\mathrm{CG}$ and AOM were showed on the Table 1.

The statistical significance $(\mathrm{p}<0.05)$ among the basal, top and entire colon crypt were showed in the Table 2. In the animals of CG there was no significant difference between the FasL expression of the top (10.75 \pm 3.33$)$ and basal (11.14 \pm 3.53$)$ colon crypt $(p=0.34293740)$. In the animals of AOM there was no significant difference between the FasL expression of the top $(8.86 \pm 4.19)$ and basal $(8.99 \pm 4.08)$ colon crypt $(p=0.78486003)$. In the animals of $\mathrm{CG}(10.95 \pm 3.43)$ and AOM $(8.92 \pm 4.13)$ there was no significant difference of the FasL expression $(\mathrm{p}=0.026466821)$. A significantly decrease on the FasL expression was observed in the animals of CG $(10.75 \pm 3.33)$ and $\operatorname{AOM}(8.86 \pm 4.19)$ in the top crypt $\left(p=0.00003755^{*}\right)$. A significantly decrease was also observed in the animals of $\mathrm{CG}$ $(11.14 \pm 3.53)$ and $A O M(8.99 \pm 4.08)$ in the basal colon crypt $(\mathrm{p}=0.00000381 * *)$.

TABLE 1 - Immunohistochemical expression of the percentage area $(\mu \mathrm{m})$ of biomarker FasL in the colon crypt (entire, top and basal) in $\mathrm{CG}$ and $\mathrm{AOM}$

\begin{tabular}{c|c|c|c|c|c|c}
\hline \multicolumn{3}{c}{ CG } & \multicolumn{3}{c}{ AOM } \\
\cline { 2 - 7 } & Crypt & Top & Basal & Crypt & Top & Basal \\
\hline Mean \pm Sd & $10.95 \pm 3.43$ & $10.75 \pm 3.33$ & $11.14 \pm 3.53$ & $8.92 \pm 4.13$ & $8.86 \pm 4.19$ & $8.99 \pm 4.08$ \\
\hline
\end{tabular}

TABLE 2 - The statistical significance of percentage area among entire, top and basal colon crypt in the CG and AOM. The $t$ student test and Shapiro-Wilks test $(\mathrm{p} \leq 0.05)$

\begin{tabular}{l|l}
\hline Control (Top crypt) X (Basal crypt) & $p=0.34293740$ \\
\hline AOM (Top crypt) X (Basal crypt) & $p=0.78486003$ \\
\hline Control (Top crypt) X AOM (Top crypt) & $p=0.00003755^{*}$ \\
\hline Control (Basal crypt) X AOM (Basal crypt) & $p=0.00000381^{* *}$ \\
\hline Control (Entire crypt) X AOM (Entire crypt) & $p=0.026466821^{* * *}$ \\
\hline
\end{tabular}

\section{Discussion}

The role of apoptosis, or programmed cell death, in the development of colon neoplasia has received increasing interest as techniques for studying the signaling pathways and genetics of this process have been developed. The mechanism of apoptotic cell death is complex ${ }^{9}$. It involves receptor-mediated protease activation, cytolytic plasma protein interactions, and ultimately distinct morphological alterations. These alterations can be observed microscopically and include DNA degradation and margination, condensation of chromatin, cell membrane alterations and the formation of apoptotic cascade ${ }^{9,10}$.
The azoxymethane is well known as inductor of oxidative stress and promote the appearance of aberrant crypt foci (ACF). The AOM-induced ACF assays have been extensively used as an endpoint in short-term carcinogenesis and chemoprevention studies $^{11,12}$. In previous reports we demonstrated the association of AOM and the occurrence of ACF in a rat model. In this research we used the similar model to induce the oxidative stress $^{13-15}$.

Apoptosis is a central feature of the regulation of colonic epithelial cell numbers. Currently, the mechanisms and control of apoptosis in colonic epithelial cell turnover are poorly understood ${ }^{16,17}$. 
Acquisition of resistance to apoptosis is thought to be crucial in the transformation of cells from normal to neoplastic in many tissues. A functional apoptotic pathway appears to be essential to maintain low numbers of mutated cells. Cells that have acquired resistances to apoptosis either before or as a result of mutational changes fail to be eliminated by apoptosis, and are in this way able to continue the progression towards a neoplastic phenotype ${ }^{15-21}$. Failure of apoptosis may be of particular importance in the development of colorectal cancer ${ }^{15,22-24}$.

There is in vitro and in vivo evidence that colon cancer cells are resistant to apoptosis mediated by Fas. Despite intracellular defects in Fas signalling in colon cancer cells, the Fas receptor is downregulated in many colonic carcinomas. Fas downregulation might be a consequence of p53 mutation at later stages of colon tumour development because Fas is a target gene for transcriptional activation by p53. Transfection of wild-type p53 into various tumour cell lines has been shown to restore/ upregulate Fas expression ${ }^{22-24}$.

The Fas (CD95/APO-1) receptor (Fas) is a cell surface receptor that mediates apoptotic cell death upon triggering by Fas ligand (FasL). The Fas is widely expressed in most cell types, including epithelial cells, and Fas mediated apoptosis may be involved in cell turnover in many tissues. The FasL also contributes to immune privilege in certain tissues where it is expressed, by triggering the apoptosis of infiltrating inflammatory cells ${ }^{15,25-27}$.

The Fas is expressed in normal colonic epithelium, and normal colonic epithelial cells are relatively sensitive to Fas mediated apoptosis. Whereas Fas is downregulated in a proportion of colonic adenocarcinomas, FasL is upregulated in most colon tumour. Coexpression of Fas and FasL occurs throughout large areas of colon tumour, yet this does not lead to increased apoptosis of the tumour cells. This is in agreement with the finding that the Fas expressed in colon carcinoma cell lines fails to transduce an apoptotic signal upon engagement with FasL ${ }^{26-28}$.

In an attempt to ascertain the significance and elucidate the underlying mechanism of Fas up-regulation in vivo, studies suggest that most low Fas-expressing (LF-) tumour up-regulate their surface Fas expression.

Given the evidence that apoptosis may play a role either in the induction or propagation of neoplastic transformation, we undertook to develop a model in which to examine FasL in aberrant colon crypts of rats.

The pattern of FasL immunoreactivity in normal epithelium was associate to the FasL expression occurring in epithelial cells at the luminal surface, but being absent from the crypt base. FasL expression by normal colonic epithelium and hyperplastic polyps was restricted to the luminal surface, where expression coincides with epithelial apoptosis ${ }^{15}$.

Stem cells participate actively in tumour origin by current concepts. In colon stem cells are located at the base of the crypts. However, in the tumorigenesis dysplastic cells are located at the apex of the crypts and luminal surface, a situation that generates controversy. We proposed to study the apoptosis in the base and apex of the crypt of colon with the biomarker-Fas ligand participating in an early stage and prior to the morphologic cellular changes, thus allowing to identify the activation of apoptosis in apex-base of the crypt and thus quantify the stimulation induces apoptosis in the crypt $^{15,29}$.
Our data demonstrated a significantly higher expression of FasL in the control animals without the stress inductor compared at the AOM group (Table 1). The low-FasL expression may be associated with an upregulated Fas expression as was reported by other authors. This may explain the higher incidence of apoptosis in this area as the model shown in other studies. On the other hand we fail in to identify a difference of FasL expression between the base and the top of crypt in the control animals (Table 2), as was related by the literature for the Fas expression. In the animals of AOM, although the expression of FasL is also lower than that presented by the control group, no significant difference between the values of FasL expressed on the top or bottom of the crypt.

Since the Fas receptor is a cell surface receptor that mediates apoptotic cell death upon triggering by FasL and it is down-expressed, it is assumed that the AOM induced an increase of apoptosis independent of being top or bottom of the crypt.

Further investigations should be conducted to establish the exact role of FasL as a mediator of the expression of Fas and consequently apoptosis. The research has important limiting factor as the model of early induction of apoptosis by AOM, although it is also widely employed in experimental models; it is well known, from samples of polyps and adenomas, that human behavior are different from experimental models in the expression of biomarkers. Either way, the findings raise an important question about the lack of differential expression of FasL between bottom and top of the crypt. However, it would be interesting that the concomitant expression of the Fas was investigated.

\section{Conclusion}

Our data suggest that AOM induced the oxidative stress identified by the significantly decrease of FasL expression, although there is no significant difference between basal and top of colon crypt linked to consumption-activation of Fas ligand, in both control or AOM groups.

\section{References}

1. Matsuno H, Tanaka Y, Aoshima H, Doi A, Matsui M, Miyano S. Biopathways representation and simulation on hybrid functional Petri net. In Silico Biol. 2003;3(3):389-404.

2. GenomicObjectNet. Apoptosis Induced by Fas Ligand. Available from URL: http://www.genomicobject.net/member3/GONET/apoptosis.html. Accessed in 27/04/2010.

3. Sun M, Fink PJ. A New class of reverse signaling costimulators belongs to the TNF family. J Immunol. 2007;179:4307-12.

4. Schulte M, Reiss K, Lettau M, Maretzky T, Ludwig A, Hartmann D, de Strooper B, Janssen O, Saftig P. ADAM10 regulates FasL cell surface expression and modulates FasL-induced cytotoxicity and activation-induced cell death. Cell Death Differ .2007;14:1040-9.

5. Humphries A, Wright NA. Colonic crypt organization and tumorigenesis: human colonic crypts. Available from URL: http://www.medscape.com/ viewarticle/578672_2. Accessed in 27/04/2010.

6. Leedham SJ, Thliveris AT, Halberg RB, Newton MA, Wrigh NA. Gastrointestinal stem cells and cancer. Stem Cell Rev Rep. 2005;1(1):233-41.

7. Humphries A, Wright NA. Colonic crypt organization and tumorigenesis. Nature Rev Can. 2008;8:415-24. 
8. Brittan M, Wright NA. Stem cell in gastrointestinal structure and neoplastic development. Gut. 2004;53:899-910.

9. West NJ, Courtney EDJ, Poullis AP, Leicester RJ. Apoptosis in the colonic crypt, colorectal adenomata, and manipulation by chemoprevention. Can Epidem Biom Prev. 2009;18:1680-3.

10. Watson AJM. The role of apoptosis in intestinal disease. J Gastroenterol. 1997;32(3):414-23.

11. Verghese JBM, Chawan CB, Shackelford L, Walker LT, Khatiwada J, Williams DS. Red palm oil suppresses the formation of azoxymethane (AOM) induced aberrant crypt foci (ACF) in Fisher 344 male rats. Food Chem Toxicol. 2006;44(10):1661-73.

12. Yasui Y, Kim M, Oyama T, Tanaka T. Colorectal carcinogenesis and suppression of tumor development by inhibition of enzymes and molecular targets. Curr Enz Inhib. 2009;5:1-26.

13. Marks G, Fagundes DJ, Ynouye CM, Pontes E RJC, Takita LC, Amaral EGS, Teruya R, Paes MC, Brasileiro JL, Aydos RD. Apoptotic effects of inositol hexaphosphate on biomarker Itpr3 in induced colon rat carcinogenesis. Acta Cir Bras. 2008;23(2):157-64.

14. Marks G, Aydos RD, Fagundes DJ, Pontes E RJC, Takita LC, Amaral EGS, Rossini A, Ynouye CM. Modulation of transforming growth factor beta2 (TGF-beta2) by inositol hexaphosphate in colon carcinogenesis in rats. Acta Cir Bras. 2006;21(4)51-6.

15. Amaral EGS, Fagundes DJ, Marks G, Ynouye CM. Study of superoxide dismutase's expression in the colon produced by azoxymethane and inositol hexaphosfate, in mice. Acta Cir Bras. 2006;21(4):27-31.

16. Bennett MW, O'Connell J, Houston A, Kelly J, O'Sullivan GC, Collins JK, Shanahan F. Fas ligand upregulation is an early event in colonic carcinogenesis. J Clin Pathol. 2001;54:598-604.

17. Frank RM, Ernest SG, Michael LJ. Regulation of intestinal epithelial cell apoptosis and the pathogenesis of inflammatory bowel disorders. J Pediatr Gastroenterol Nutr. 2002;34(3):254-60.

18. Qu W, Ke H, Pi J, Broderick D,French JE, Webber MM, WaalJkes MP. Acquisition of apoptotic resistance in cadmium-transformed human prostate epithelial cells: bcl-2 over-expression blocks the activation of JNK signal transduction pathway. Environ Health Perspect. 2007;115(7):1094-100.

19. Madhukar BV, Trosko JE. The causes of cancer: implications for prevention and treatment. Indian J Pediatr.1997;64(2):131-41.
20. Rochette PJ, Brash DE. Progressive apoptosis resistance prior to senescence and control by the anti-apoptotic protein BCL-xL. Mech Ageing Dev. 2008;129(4):207-14.

21. Huerta S, Goulet E, Livingston E. Colon cancer and apoptosis. Am J Surg. 2008;191(4):517-26.

22. Huerta S, Heinzerling J, Anguiano-Hernandez Y, Huerta-Yepez S, Lin J, Chen D, Bonavida B, Livingston E. Modification of gene products involved in resistance to apoptosis in metastatic colon cancer cells: roles of Fas, Apaf-1, NFkB, IAPs, Smac/DIABLO, and AIF. J Surg Res. 2008;142(1):184-94.

23. Watson AJM. Apoptosis and colorectal cancer. Gut. 2004;53:1701-09. 24. Liu K, McDuffie E, Abrams SI. Exposure of human primary colon carcinoma cells to anti-Fas interactions influences the emergence of pre-existing Fas-resistant metastatic subpopulations. J Immunol. 2003;171:4164-74.

25. Peli J, Schröter M, Rudaz C, Hahne M, Meyer C, Reichmann E, Tschopp J. Oncogenic Ras inhibits Fas ligand-mediated apoptosis by downregulating the expression of Fas. EMBO J. 1999;18(7):1824-31.

26. Cardier JE, Schulte T, Kammer H, Kwak J, Cardier M. Fas (CD95, APO-1) antigen expression and function in murine liver endothelial cells: implications for the regulation of apoptosis in liver endothelial cells. FASEB J. 1999;13:1950-60.

27. Reichmann E. The biological role of the Fas/FasL system during tumor formation and progression. Semin Cancer Biol. 2002;14(2):309-15. 28. Fingleton B, Carter JK, Matrisian LM. Loss of functional Fas ligand enhances intestinal tumorigenesis in the min mouse model. Cancer Res. 2007;67(10):4800-6.

29. Bruckner HW, Merrick JPM. Adenocarcinoma of the colon and rectum. Cancer Medicine 5th edition. Available from URL: http:// www.ncbi.nlm.nih.gov/bookshelf/br.fcgi?book=cmed\&part=A24990. Accessed in 26/04/2010.

\section{Acknowledgement}

The authors thank Ms. Maria do Carmo Negrini Fagundes for her assistance in formatting the English language.

Conflict of interest: none Financial source: none

\section{Correspondence:}

Djalma José Fagundes

Rua Camé, 244/33

03121-020 São Paulo - SP Brasil

Phone: (55 11)2604-4408

djfagundes.dcir@epm.br

Received: March 10, 2010

Review: May 17, 2010

Accepted: June 21, 2010

\section{How to cite this article}

Bussuan LAM, Fagundes DJ, Marks G, Bussuan PM, Teruya R. The role of Fas ligand protein in the oxidative stress induced by azoxymethane on crypt colon of rats. Acta Cir Bras. [serial on the Internet] 2010 Nov-Dec;25(6). Available from URL: http://www.scielo.br/acb

*Color figures available from www.scielo.br/acb 